\title{
A Paradox Perspective on Corporate Sustainability: Descriptive, Instrumental, and Normative Aspects
}

\author{
Tobias Hahn ${ }^{1} \cdot$ Frank Figge $^{1} \cdot$ Jonatan Pinkse $^{2} \cdot$ Lutz Preuss $^{3}$
}

Received: 25 February 2017/ Accepted: 18 May 2017/Published online: 7 June 2017

(C) The Author(s) 2017. This article is an open access publication

\begin{abstract}
The last decade has witnessed the emergence of a paradox perspective on corporate sustainability. By explicitly acknowledging tensions between different desirable, yet interdependent and conflicting sustainability objectives, a paradox perspective enables decision makers to achieve competing sustainability objectives simultaneously and creates leeway for superior business contributions to sustainable development. In stark contrast to the business case logic, a paradox perspective does not establish emphasize business considerations over concerns for environmental protection and social well-being at the societal level. In order to contribute to the consolidation of this emergent field of research, we offer a definition of the paradox perspective on corporate sustainability and a framework to delineate its descriptive, instrumental, and
\end{abstract}

Editorial Essay Thematic Symposium: Paradoxes in Corporate Sustainability: Managing Tensions between Social, Economic, and Environmental Issues.

Jonatan Pinkse

jonatan.pinkse@manchester.ac.uk

Tobias Hahn

tobias.hahn@kedgebs.com

Frank Figge

figge@sustainablevalue.com

Lutz Preuss

L.Preuss@sussex.ac.uk

1 KEDGE Business School, Domaine de Luminy, BP 921, 13288 Marseille Cedex 9, France

2 Alliance Manchester Business School, The University of Manchester, 8.10, Harold Hankins, Booth Street West, Manchester M15 6PB, UK

3 School of Business, Management and Economics, University of Sussex, Jubilee Building, Brighton BN1 9RH, UK normative aspects. This framework clarifies the paradox perspective's contents and its implications for research and practice. We use the framework to map the contributions to this thematic symposium on paradoxes in sustainability and to propose questions for future research.

Keywords Corporate sustainability $\cdot$ Paradox $\cdot$ Descriptive aspects · Instrumental aspects · Normative aspects . Business case $\cdot$ Research agenda

\section{Introduction}

Building on research on paradox in the management literature (Schad et al. 2016), there is an emerging stream of research that applies a paradox lens to corporate sustainability (for a recent review, see Van der Byl and Slawinski 2015). A paradox perspective on corporate sustainability explicitly acknowledges tensions among different desirable, yet interdependent and, at times, conflicting sustainability objectives such as environmental protection and social well-being (Hahn et al. 2015). By accepting and working through such tensions, a paradox approach enables decision makers to achieve competing sustainability objectives simultaneously. Moreover, a paradox perspective creates leeway for superior business contributions to sustainable development because it regards environmental and social concerns as an end in themselves, not just as a means to the end of profit maximization (Hahn et al. 2010; Nijhof and Jeurissen 2010). A paradox perspective thus stands in stark contrast to research emphasizing the business case for sustainability according to which firms will benefit financially when they address environmental and social concerns (Porter and Kramer 2011; Carroll and Shabana 2010; Salzmann et al. 2005; Schreck 2011). The 
business case considerably limits the potential contribution of firms to sustainable development because it establishes a primacy of financial outcomes at the firm level over concerns for environmental protection and social well-being at the societal level (Margolis and Walsh 2003; Hahn and Figge 2011).

Notwithstanding its promise to change our understanding of corporate sustainability, the paradox perspective is still in its infancy and lacks commonly shared definitions and frameworks. In this paper, we contribute to consolidating this emerging field of research by offering key definitions and by delineating its descriptive, instrumental, and normative aspects (cf. Donaldson and Preston 1995). At its core, a paradox perspective on corporate sustainability embraces tensions to simultaneously accommodate competing yet interrelated economic, environmental, and social concerns that reside at different levels and operate in different logics and time frames and in different spatial scales (Hahn et al. 2014, 2015). In analyzing it from descriptive, instrumental, and normative angles, respectively, we develop a framework that clarifies both the paradox perspective's contents and its implications for research and practice. This framework not only organizes the contributions to this thematic symposium on paradoxes in corporate sustainability, but also offers direction for research that challenges the primacy of corporate financial performance over environmental and social concerns. We argue that a paradox perspective offers the conceptual foundations for a shift beyond the business case toward "management theory as if sustainability matters" (Gladwin et al. 1995, p. 896).

In the remainder of this paper, we first define the paradox perspective on corporate sustainability and delineate it from the dominant business case view. We then develop our framework on descriptive, instrumental, and normative aspects of such a paradox perspective. Before concluding the paper, we use this framework to map the contributions of this thematic symposium and offer an outlook on future research opportunities.

\section{Corporate Sustainability at the Crossroads: Paradox or Business Case?}

\section{Corporate Sustainability}

Referring back to the system-level concept of sustainable development (WCED 1987), Bansal (2005) defines corporate sustainability as the intersection of the three principles: environmental integrity, social equity, and economic prosperity. While for-profit firms play a key role in sustainable development, because they represent the productive resources of the economy (Bansal 2002), "individual organizations cannot become sustainable: Individual organizations simply contribute to the large system in which sustainability may or may not be achieved" (Jennings and Zandbergen 1995, p. 1023). By definition, corporate sustainability thus represents a levelspanning concept that links organizational activities to outcomes at overarching societal and natural systems in that "business firms are expected to improve the general welfare of society" (Schwartz and Carroll 2008, p. 168).

Corporate sustainability is furthermore characterized by a multitude of different economic, environmental, and social objectives that all appear desirable in isolation but are "inextricably connected and internally interdependent" (Bansal 2002, p. 123). The ambition of sustainability to address these multiple objectives simultaneously results in tensions since progress on one sustainability issue might have detrimental effects for other sustainability issues. Moreover, sustainability is based on a long-term orientation to include the needs of future generations instead of the oftentimes short-term focus of firms (Held 2001; Slawinski and Bansal 2015). It also seeks equitable development opportunities for developed and less developed regions (Zuindeau 2007). As a consequence, corporate sustainability is inherently laden with tensions between different dimensions at different levels that reside at different temporal and spatial scales (Berger et al. 2007; Hahn et al. 2015).

\section{Paradox Perspective}

Whereas the existence of inherent tensions in corporate sustainability, and in related concepts such as corporate social responsibility, has been highlighted by numerous authors for quite some time (Aram 1989; Kaptein and Wempe 2001; Vilanova et al. 2009; Margolis and Walsh 2003; Calton and Payne 2003; Kallio 2007; Haffar and Searcy 2015; Van der Byl and Slawinski 2015), only recently has paradox theory been used as a theoretical lens to conceptualize corporate sustainability (Hahn et al. 2014, 2015; Gao and Bansal 2013; Slawinski and Bansal 2015). Paradox theory in management posits that paradoxes, i.e., "persistent contradiction between interdependent elements" (Schad et al. 2016, p. 6), are ubiquitous phenomena in organizations, resulting in tensions between various aspects that "seem logical in isolation but absurd and irrational when appearing simultaneously" (Lewis 2000, p. 760). A paradox perspective "explores how organizations can attend to competing demands simultaneously" and argues that the long-term success of an organization "requires continuous efforts to meet multiple, divergent demands" (Smith and Lewis 2011, p. 381). Organizations and decision makers may either respond defensively or proactively to paradoxical tensions, yet 
Smith and Lewis (2011) argue that generative outcomes where the "awareness of tensions [triggers] a management strategy of acceptance rather than defensiveness" (p. 391) depend on the ability to embrace tensions instead of avoiding them.

Building on these foundations in paradox theory, we propose the following definition: A paradox perspective on corporate sustainability accommodates interrelated yet conflicting economic, environmental, and social concerns with the objective of achieving superior business contributions to sustainable development. Rather than seeking to align environmental and social aspects with financial performance to eliminate tensions (as the business case does), a paradox perspective fosters strategies that accept tensions and attend to different sustainability objectives simultaneously, even if they are conflicting (Gao and Bansal 2013; Hahn et al. 2015). At its core, the paradox perspective provides the conceptual foundations for an approach to corporate sustainability that accepts tensions between economic, environmental, and social concerns that reside at different levels and operate at different temporal and spatial scales in order to achieve more substantive business responses to multiple sustainability challenges. It invites firms and decision makers to accept and live with tensions in sustainability and enables them to address multiple environmental and social concerns, even in the absence of immediate business benefits, for instance by addressing sustainability challenges early on when business benefits are still unclear (Rivoli and Waddock 2011) or by engaging with fringe stakeholders with little or no direct business relevance (Hart and Sharma 2004).

While it alleviates the constraint of immediate business benefits from corporate sustainability, a paradox perspective does not mean that firms abandon a profit orientation altogether. Rather, "paradoxical resolution denotes purposeful iterations between alternatives in order to ensure simultaneous attention to them over time" (Smith and Lewis 2011, p. 392). A paradox perspective thus creates leeway for more substantive corporate contributions to sustainable development by purposefully balancing and combining instrumental initiatives-where addressing sustainability issues yields business benefits-with moral initiatives-where firms address environmental and social issues in their own right (Hahn et al. 2016). In this way, firms will address a wider range of sustainability issues to a fuller extent because they will not only focus on those that offer immediate business benefits.

As Lüscher and Lewis (2008, p. 234) find, accepting and "working through" paradox enables organizational change, not by "eliminating or resolving paradox, but [by] constructing a more workable certainty" when dealing with tensions. By doing so, it alleviates the paralysis that decision makers often experience when confronted with tensions. Accordingly, a paradox perspective on corporate sustainability proposes that accepting and working through the tensions around sustainability enables change in, of, and by firms toward sustainable development. To illustrate how sustainability concerns can be addressed through a paradox perspective, we apply Smith and Lewis (2011) four types of paradoxes: paradoxes of belonging, learning, organizing, and performing.

Paradoxes of belonging refer to tensions around individual and collective identities and between different values and roles (Smith and Lewis 2011). In the context of corporate sustainability, such tensions occur, for instance, when organizational members hold competing values and identities with regard to environmental and social concerns (Aguilera et al. 2007; Wright et al. 2012; Ghadiri et al. 2015; Allen et al. 2015). Where such tensions of belonging are perceived in terms of either/or-dilemmas between personal and organizational views, one will be subordinated to the other, and organizational members are likely to disconnect from or even overtly oppose the organization's sustainability activities (Rodrigo and Arenas 2008).

By contrast, accommodating conflicting personal and organizational identities and values around sustainability can foster change for sustainability, since the coexistence of conflicting identities and values within the organization can drive cognitive organizational reorientation (Fiss and Zajac 2006), organizational creativity (Woodman et al. 1993) and organizational learning (Huzzard and Östergren 2002). Firms can foster the coexistence of competing identities and values, for instance, by creating structures and temporal pockets in the organization where alternative individual identities and values can flourish - and eventually feed back into the organization so that the confrontation with diverging identities and values nurtures a productive process of progress (Sundaramurthy and Lewis 2003). Such a productive engagement with sustainability is unlikely to occur if tensions of belonging are undermined or eliminated by seeking to align personal values or identities with the dominant organizational ones.

Paradoxes of learning describe tensions between existing and novel activities during processes of renewal, change, and innovation (Smith and Lewis 2011). Since sustainable development involves a transition from currently unsustainable to more sustainable business practices and requires firms to fundamentally alter their current patterns of activity, paradoxes of learning are highly relevant for corporate sustainability. In firms, tensions around learning for sustainability occur between the need to radically depart from currently unsustainable business practices and products and the need to build upon existing routines and systems (Kolk and Pinkse 2008). Pursuing an either/or logic results either in an excessive reliance on radical and disruptive innovation-which jeopardizes the 
feasibility and widespread dissemination of sustainable innovations-or in a bias toward incremental changewhich falls short of the scale of change that is required to effectively address sustainability challenges.

Change toward more sustainable business models (Boons and Lüdeke-Freund 2013) requires simultaneously building upon and destroying current activities (O'Reilly and Tushman 2008) to create novel, more sustainable organizational forms and practices. From a paradox perspective, such "tension between [...] existing business models and the radical innovations necessary to achieve systemic innovation towards long term sustainable development" (Midttun 2007, p. 409) can be addressed through organizational ambidexterity, i.e., the ability to simultaneously pursue explorative and exploitative activities for sustainable innovations (Maletič et al. 2014). Accordingly, engaging with paradox has been found to foster creativity and innovation (Miron-Spektor et al. 2011).

Paradoxes of organizing stem from the structure and leadership of organizations and manifest themselves in tensions around collaboration and competition, empowerment and direction, and flexibility and control (Smith and Lewis 2011). There is an ongoing debate as to how sustainability activities should be organized and structured and to what extent sustainability activities can be integrated into the core structure of the organization (Yuan et al. 2011; Griffiths and Petrick 2001). If organizations decide to either fully integrate or completely separate sustainability activities, they either subdue sustainability initiatives to the dominant commercial logic of daily business operations-leaving no leeway for longer-term and more fundamental considerations-or they marginalize sustainability initiatives at the periphery of the organization.

A paradox perspective keeps the tension between structural separation and integration open. While some sustainability activities become integrated with core business routines and structures to allow for commercial benefits, other activities are deliberately kept separate to create space for sustainability initiatives to "flourish independently of prevailing business practices" (Yuan et al. 2011, p. 77) in order to address sustainability concerns beyond commercial considerations (Hahn et al. 2016). In addition, tightly and loosely coupled structures can be coordinated through cross-functional interfaces and network structures that combine different independent units horizontally (Griffiths and Petrick 2001; Gupta and Govindarajan 2000). Living with the tension between different structural forms of sustainability activities through a paradox perspective thus enhances the simultaneous pursuit of commercially beneficial sustainability measures on the one hand and morally driven ones on the other.

Finally, paradoxes of performing refer to tensions around the plurality of competing organizational goals in the face of divergent stakeholder demands (Smith and Lewis 2011). Paradoxes of performing touch the very heart of corporate sustainability and its ambition to contribute to a diverse set of potentially competing sustainability issues, such as climate change, biodiversity conservation, poverty alleviation, public health, or education. Following an either/or perspective, firms will perceive these tensions as multiple dilemmas. Given the dominance of a commercial logic in business organizations, firms will seek to eliminate these dilemmas by selectively picking those environmental and social concerns where business benefits can be expected, dismissing all other sustainability concerns in the process.

A paradox perspective on performing tensions embraces conflicts between different performance domains in sustainability and seeks to attend to multiple competing sustainability goals simultaneously. To work through performing paradoxes, firms engage in ongoing improvisation to attend to the multiple performance areas in a balanced way (Beech et al. 2004; Clegg et al. 2002). Sustainability concerns that might be in conflict with the organizational goal of profitability will thus not be excluded. Rather, contradictory sustainability aspects are juxtaposed without emphasizing one aspect as "best option." In this way, the performing paradox is kept open and works as an invitation to simultaneously act on multiple economic, social, and environmental outcomes.

\section{Beyond the Business Case}

It is evident that a paradox perspective on corporate sustainability stands in stark contrast to the dominant business case perspective. While early writings on corporate sustainability were deeply embedded in a systems logic that takes into account the level-spanning and multifaceted nature of corporate sustainability (Purser et al. 1995; Gladwin et al. 1995), over the last two decades "[m]uch of the research on organizational responses to social and environmental issues [...] has been framed around an instrumental logic, i.e., how firms can benefit from addressing societal concerns" (Gao and Bansal 2013, p. 241). The business case for sustainability is based on the dominance of economics language (Ferraro et al. 2005) and appropriates sustainability in terms of narrow business interests (Banerjee 2008; Welford 1997). The business case logic conceptualizes corporate sustainability solely at the organizational level and seeks to eliminate tensions by aligning environmental and social concerns with the end of improving corporate financial performance (Hahn et al. 2014).

Most importantly, under a business case logic, environmental and social concerns are not seen as having intrinsic value. Consequently, contributions to sustainable 
development will be limited to those sustainability aspects that promise to result in positive effects on the economic performance or the market position of the firm within a comprehensible timeframe (McWilliams and Siegel 2011). This reductionist and instrumental logic of the business case leaves little room for radical shifts in business practices since it seeks to translate responses to intricate sustainability issues into measurable and controllable management tasks that fit with conventional business models and practices. This selective and purely instrumental alignment of sustainability aspects with business outcomes and established business routines limits the scope and scale of corporate contributions to sustainable development: Business case strategies consider sustainability objectives only if, and only to the extent that, they promise business benefits. Hence, as Nijhof and Jeurissen (2010, p. 618) succinctly summarize, the "business case approach results in opportunism, leaves institutional blockades intact and drives out the intrinsic motivation for engaging in [sustainability]".

Overall, a paradox perspective on corporate sustainability not only considerably widens the scale and the scope of corporate contributions to sustainability; it also offers the theoretical foundations for a conceptualization of corporate sustainability that removes the limitations that result from the primacy of business benefits over environmental and social concerns.

\section{Descriptive, Instrumental, and Normative Aspects of a Paradox Perspective}

To further develop research into tensions and paradoxes in corporate sustainability, we distinguish between descriptive, instrumental, and normative aspects of a paradox perspective on corporate sustainability and subsequently discuss their interconnections. To clarify the content of a paradox perspective on corporate sustainability and highlight its significance and implications, we develop on its "descriptive accuracy, instrumental power, and normative validity" (Donaldson and Preston 1995, p. 65). These three aspects outline, respectively, the descriptive categories that capture how firms respond to tensions in sustainability, address the consequences of sustainability paradoxes and their underlying mechanisms, and reflect on the normative foundations of a paradox perspective on corporate sustainability. In the following, we provide an outline of descriptive, instrumental, and normative aspects of a paradox perspective on sustainability separately, before addressing connections between them. Figure 1 serves to structure this discussion, to organize the contributions to this thematic symposium, and to identify opportunities for further research.

\section{Descriptive}

A paradox perspective on corporate sustainability has important descriptive aspects. It can be used to describe and explain how firms and decision makers deal with paradoxical tensions around multiple sustainability issues, which relies on descriptive categories that accurately capture organizational phenomena around such tensions. From a descriptive perspective, relevant empirical questions include (cf. Schad et al. 2016): Does a paradoxical perspective offer more accurate descriptions of managers' and businesses' responses to sustainability challenges (for instance, in comparison with a business case view)? What types of paradoxes do decision makers and firms perceive when being confronted with sustainability issues? What kinds of strategy do individuals and organizations develop to respond to tensions around sustainability issues?

Empirical research on tensions and paradoxes in corporate sustainability is still rather scant (Van der Byl and Slawinski 2015). As one example, Slawinski and Bansal (2015) examine how organizations attend to the tensions between short-term and long-term orientations around corporate sustainability. Jay (2013) describes the process through which decision makers in a sustainable hybrid organization navigate paradoxical tensions between different organizational outcomes. Ghadiri et al. (2015) investigate how CSR consultants manage the tensions between profit and social responsibility and find evidence for "paradoxical identity mitigation" where professionals simultaneously embrace and distance themselves from competing demands. Berger et al. (2007) identify firms that follow a so-called syncretic stewardship model in that they try to simultaneously cater for economic, social, and environmental demands through constant balancing and negotiation.

Given the dearth of descriptive studies on tensions in corporate sustainability, there remain important gaps. One important area refers to different types of paradoxes that can occur around sustainability. For instance, we do not yet know whether firms and decision makers experience additional types of paradoxes, beyond belonging, organizing, learning, and performing (Smith and Lewis 2011), that are more specific to corporate sustainability (for a conceptual categorization of tensions in social enterprises, see Smith et al. 2013). Another important area refers to the strategies that firms and decision makers use to respond to tensions in corporate sustainability. Of course, generic response strategies to paradox have been proposed (Poole and Van de Ven 1989), and there is some evidence underlining their utility from neighboring fields such as social entrepreneurship (Battilana et al. 2015), yet there is still little research on the specific forms of paradoxical responses to tensions in sustainability. Relatedly, we need a better understanding of 


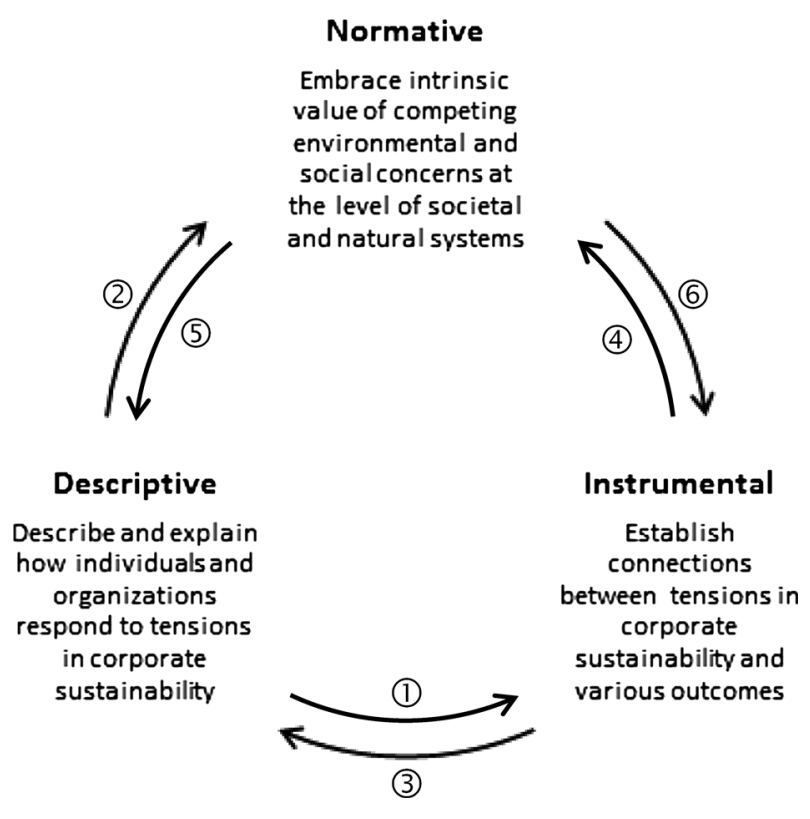

Fig. 1 Descriptive, instrumental, and normative aspects of a paradox perspective on corporate sustainability

the antecedents and boundary conditions of paradoxical responses to sustainability concerns.

\section{Instrumental}

Instrumental aspects of a paradox perspective on corporate sustainability seek to establish connections with various outcomes (cf. Donaldson and Preston 1995). They refer to the consequences of paradoxical tensions and the different ways to (mis)manage these, including detrimental and generative outcomes (cf. Schad et al. 2016). In this context, a paradox perspective on corporate sustainability includes but explicitly goes beyond organizational level outcomes and also considers outcomes in overarching societal or natural systems and adopts short- and long-term timeframes (Slawinski and Bansal 2012). Instrumentality can refer to all three dimensions of sustainability, with no a priori emphasis of one dimension over others (Hahn and Figge 2011). This means that inquiry into the consequences of corporate sustainability does not necessarily have to refer to economic or financial outcomes but can also highlight environmental or social outcomes or multiple objectives (Mitchell et al. 2016). Relevant questions in this context are: Does a paradoxical approach to corporate sustainability lead to stronger corporate contributions to sustainability in terms of positive economic, environmental, and/or social impacts? What are the underlying mechanisms of a paradoxical perspective on corporate sustainability that may lead to superior sustainability outcomes? Does working through tensions in sustainability have specific positive or negative outcomes in performance areas other than sustainability?
Examples of existing instrumental studies based on a paradox perspective include Scherer et al. (2013) who argue that a paradox approach to competing sustainability demands will most likely help firms to maintain their legitimacy. Hahn et al. (2016) propose that firms that are able to balance and combine profit-oriented and morally driven social initiatives in an ambidextrous manner will achieve higher levels of positive environmental and social impact. Richardson and Cragg (2010) discuss the tensions between financial and ethical outcomes in socially responsible investments.

While there is an impressive body of literature on the financial consequences of adopting environmental and social initiatives based on the business case (Schreck 2011; Orlitzky et al. 2003; Margolis and Walsh 2003), we lack systematic empirical analyses of the economic, social, and environmental outcomes of a paradox approach to sustainability. The paradox literature has offered evidence on the mechanisms behind generative outcomes of embracing paradoxical tensions, for instance in the context of innovation (Raisch and Birkinshaw 2008), creativity (MironSpektor et al. 2011), and corporate governance (Sundaramurthy and Lewis 2003). However, we do not know whether the same performance effects and underlying mechanisms also apply in the context of corporate sustainability or to what extent the specific, level-spanning and multifaceted nature of corporate sustainability requires distinct mechanisms to generate sustainability outcomes.

\section{Normative}

A paradox perspective on corporate sustainability has a strong normative core. It is based on the conviction that firms have a responsibility that goes beyond financial performance and shareholder interests. It also builds upon the idea that competing environmental and social concerns at the level of overarching societal and natural systems have intrinsic value. Accordingly, these concerns represent objectives for their own sake, irrespective of their ability to further financial or shareholder interests (cf. Donaldson and Preston 1995). A paradox perspective on corporate sustainability invites alternative normative positions on the objective function of the firm and hence underpins the notion of "a multi-objective corporation as a means for enabling a greater range of management decisions so as to permit more direct corporate engagement in the diverse goals of various stakeholders" (Mitchell et al. 2016, p. 252). In accordance with its explicit objective to achieve superior business contributions to sustainable development, a paradox perspective creates leeway for the full consideration of the intrinsic value of multiple sustainability issues (e.g., future generations, biodiversity, and poverty alleviation) irrespective of their value for business. By 
doing so, it offers a platform for the normative debate of the role of business in the wider context of sustainable development (van Marrewijk and Werre 2003; Steurer et al. 2005).

While there is ample literature on the normative foundations of corporate sustainability and neighboring concepts (Garriga and Melé 2004; Quinn and Jones 1995), to the best of our knowledge, there is no literature that specifically addresses the normative foundations of a paradox perspective on corporate sustainability. Relevant questions in this context include: How can a paradox perspective on corporate sustainability be normatively justified as opposed to the utilitarian foundations of the business case? What are suitable moral grounds to justify the demand that firms balance different, equally relevant but competing sustainability challenges? To what extent are there normative limitations to keeping tensions and conflicting situations around sustainability concerns open?

A major gap in this context refers to the need for a normative justification of a paradox perspective on corporate sustainability. The wider sustainability debate has been marked by an ongoing discussion of the extent to which the depletion and substitution of natural resources is justifiable under a sustainable regime (Neumayer 1999). This debate is reflected in the opposition of technocentric versus ecocentric conceptions of corporate sustainability (Gladwin et al. 1995). It requires further elaboration how a paradox perspective on corporate sustainability could be positioned within this spectrum of sustainability conceptions-and how balancing or even compromising between different sustainability concerns can be justified normatively.

\section{Interconnections}

As Donaldson and Preston (1995) highlight, descriptive, instrumental, and normative aspects are mutually supportive. In the following, we therefore shed light on the interconnections between these three aspects of a paradox perspective on corporate sustainability. A better understanding of how descriptive, instrumental, and normative aspects are connected facilitates the design of robust and meaningful inquiries into corporate sustainability based on a paradox perspective. These interconnections-depicted as arrows in Fig. 1-help us to identify opportunities for future research and provide the background for mapping the contributions of this thematic symposium.

Descriptive aspects can inform instrumental research inasmuch as they prepare the ground for testing instrumental predictions [see arrow (1) in Fig. 1]. Descriptive accounts of differences in how managers and firms deal with sustainability tensions can serve as independent constructs in instrumental inquiries and offer explanatory power for organizational- or societal-level outcomes of corporate sustainability. For instance, different managerial responses to tensions around climate change could be tested with regard to their explanatory power for predicting corporate carbon performance. Likewise, the descriptive identification of different types of sustainability tensions invites instrumental analyses of the consequences of the prevalence of different types of paradoxical tensions. Accordingly, researchers could study if different sustainability outcomes are associated with paradoxes of belonging, organizing, learning, or performing.

Descriptive aspects can inform normative studies on paradox and corporate sustainability [see arrow (2)], although they cannot be used to test the normative foundations of a paradox perspective (cf. Donaldson and Preston 1995). Descriptive accounts of alternative normative positions of managers and firms on the finality of firms offer valuable insights for normative inquiries into how managers and firms actually justify sustainability initiatives that go beyond the business case. Accordingly, descriptive findings regarding what norms and values decision makers leverage to justify the simultaneous pursuit of conflicting sustainability objectives can highlight the relevance of different normative theories as foundations for a paradox perspective on corporate sustainability.

Instrumental inquiries into the consequences of a paradox perspective on corporate sustainability can likewise enhance descriptive research [see arrow (3)]. By identifying relevant characteristics and mechanisms of a paradox perspective that have instrumental value for sustainable development, instrumental studies offer useful categories and lenses for descriptive studies into the conditions under which characteristics and mechanisms for the achievement of superior sustainability outcomes through a paradox approach can actually be found. For instance, there is evidence that managers' ability for paradoxical thinking has instrumental value for creativity (Miron-Spektor et al. 2011). Similar findings of instrumental studies into the consequences of paradoxical thinking with regard to sustainability outcomes would indicate that descriptive studies of the antecedents of paradoxical thinking among managers are particularly relevant.

Instrumental studies are also linked to normative aspects [see arrow (4)]. By establishing links between means and ends, instrumental research refers to the finality of organizations' activities. This finality is ultimately value-laden since any position on the purpose and the objective function of the firm rests on a normative foundation (Freeman et al. 2004; Donaldson and Walsh 2015). Instrumental approaches help to identify the role of paradoxical mechanisms in achieving normatively desirable organizational contributions to sustainable development. By showing whether and which sustainability outcomes are likely to be 
achieved through a paradox perspective, instrumental studies can help to identify gaps between actual sustainability performance and the normative principles underlying corporate sustainability. For instance, instrumental studies into the intergenerational outcomes of corporate sustainability initiatives can identify whether or not a paradox approach to sustainability initiatives measures up to the normative requirements of sustainable development.

Finally, normative aspects influence descriptive [see arrow (5)] and instrumental approaches [see arrow (6)]. Normative approaches and theories inform descriptive studies by offering multiple descriptive categories on how managers and firms position themselves with regard to sustainable development which can be used as lenses in descriptive analyses. This link invites descriptive inquiries into the normative and moral constitution of firms and decision makers to identify to what extent there exists some paradoxical orientation beyond the business case among managers and firms. Normative aspects also inform instrumental inquiries into the consequences of a paradox perspective on corporate sustainability by offering prescriptive categories for desirable outcomes of corporate activities with regard to sustainable development. They define the various goals and outcomes a paradoxical perspective on corporate sustainability should contribute to. For instance, sustainable development as a normative concept provides instrumental studies into the consequences of corporate sustainability initiatives with pertinent outcome variables, for instance with regard to interand intra-generational equity (Padilla 2002) or planetary carrying capacities (Whiteman et al. 2013).

\section{Research Opportunities}

A paradox perspective on corporate sustainability provides the conceptual foundations for "[o]rganizational inquiry [to] go beyond efforts to reconcile corporate responses to social misery with the neoclassical model of the firm, $[\ldots]$ [where] social and economic tension should serve as a starting point for new theory and research" (Margolis and Walsh 2003, p. 280). Distinguishing between descriptive, instrumental, and normative aspects of a paradox perspective helps scholars to identify opportunities for further research. In the following, we sketch out the six contributions to this thematic symposium and map them in our framework according to their main focus and to the interconnections they establish between the three aspects (see Fig. 2). We then explore opportunities for further research on a paradox perspective on corporate sustainability along descriptive, instrumental, and normative routes.

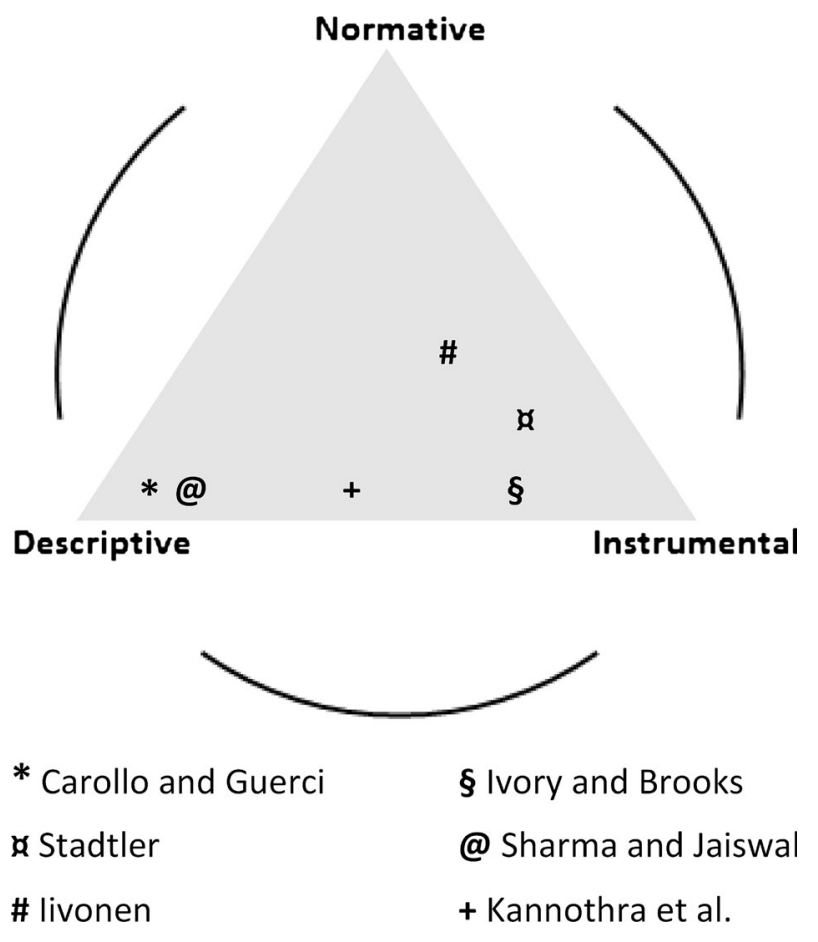

Fig. 2 Characterization of the contributions to the thematic symposium

\section{Descriptive Focus}

This thematic symposium contains three articles with a mainly descriptive focus. These articles have in common that they seek a better understanding of how firms and decision makers deal with sustainability-related tensions.

In their article, Carollo and Guerci (2017) analyze how sustainability managers in Italian firms deal with tensions in their identity construction processes. They identify three main tensions in the identity work of sustainability managers: between business and values orientation, between organizational insiders and outsiders and between shortterm and long-term aspects of their identity work. Through their study, they contribute to a more fine-grained understanding of paradoxes of belonging (Smith and Lewis 2011) in the context of corporate sustainability. In addition, they provide evidence for the occurrence of paradoxical thinking among sustainability managers as they find that some used paradoxical responses to live up to both competing poles of the respective tensions simultaneously. They juxtapose these paradoxical approaches with those managers who responded in an either/or manner and settled on one pole of the tensions.

As a further contribution, they identify metaphorical reasoning as a coping mechanism that underlies paradoxical responses by sustainability managers to tensions in their identity work. More precisely, their findings reveal that 
either/or responses and paradoxical responses to identity tensions around sustainability rely on different types of metaphors, polarizing metaphors and bridging metaphors, respectively. These insights offer valuable evidence on paradoxical response strategies that are used by decision makers to deal with tensions around sustainability.

Kannothra, Manning, and Haigh (2017) investigate how so-called Impact Sourcing Service Providers deal with the tension between offering IT and related services on a competitive basis while hiring and training people from disadvantaged groups in their local communities. They describe how the dual embeddedness of such firms in their local communities, on the one hand, and in global supply chains, on the other hand, creates a paradox of performing (Smith and Lewis 2011), in particular concerning how they approach growth. Moving onto instrumental ground, they show how the firms in their sample have opted for either "community-focused" growth, where they settle for slower growth within the constraints of established relationships within their communities, or for "client-focused" growth, faster growth that is driven by an aspiration to expand but where the firm ends up managing client and community relations separately. These growth orientations are inextricably linked with other paradoxes, not least paradoxes of learning, for example regarding different ways in which tensions are perceived and managed, or paradoxes of belonging, such as which strategies are viable and acceptable to the firms and their founders in the first place. Lastly, the authors draw attention to the importance of geographic embeddedness and distance for the paradox literature.

Sharma and Jaiswal (2017) describe different cognitive frames held by individuals at different levels of an organization. They analyze how these frames interact and what these interactions imply for managing sustainability tensions. Using the example of a Bottom of the Pyramid (BOP) project of a global pharmaceutical company, they show that paradoxical, business case, and business frames were held at different levels of the organization and at different times. In their article, Sharma and Jaiswal offer a dynamic model of how organizations manage sustainability tensions. They build on existing research on cognitive frames in sustainability (Sharma and Good 2013; Hahn et al. 2014) that they criticize for using cognitive frames as ready-to-wear mental templates. Accordingly, they add to this body of research by proposing a dynamic model of cognitive frames. In their case study, they identify a convergence of the cognitive frames of project leaders and organizational leaders. In addition, they show how decision making horizons mediate sustainability frames. Building among others on Reinecke and Ansari (2015) and Slawinski and Bansal (2015), they identify bottom-up temporal work, and, building on Staudenmayer et al. (2002), they identify event-based temporal shifts as two mechanisms to explain shifts in cognitive frames.

\section{Instrumental Focus}

The articles of this thematic symposium with a mainly instrumental focus seek to explain the outcomes of different approaches to tensions in corporate sustainability and to identify and understand the mechanisms that underlie such outcomes.

The study of Iivonen (2017) examines how beverages giant The Coca-Cola Company deals with the tension between its core business model and the social issue of obesity. The main focus of this study is to understand the mechanism that the firm employs to protect its business model against threats from increasing calls for changes in the offerings of food and drink companies as a response to the obesity epidemic (Stuckler et al. 2012; Kleiman et al. 2012). The author identifies the defensive response of projection through which Coca-Cola seeks to separate the issue of obesity from the tensions and responsibilities that are associated with it. She shows that by purposefully constructing the issue of obesity and the role of consumers in a paradoxical manner, the company seeks to divert attention from the tensions between obesity and its business model.

This study makes several contributions at the intersection of descriptive and instrumental aspects. It reveals a very instrumental, if not opportunistic, approach to tensions in corporate sustainability and shows that the active management of tensions around a sustainability issue does not necessarily result in generative outcomes for the social cause. Rather, as this case study shows, paradoxes can be actively managed toward the end of achieving commercial objectives, while-normatively speaking-undermining the intrinsic value of the social issue. While discursively embracing the issue of obesity, projecting the responsibility and tensions with regard to dietary choices and obesity upon consumers allows the company to divert the tensions from its core business model. This study thus advances our understanding of defensive responses to paradoxical tensions (Schad et al. 2016) and highlights that there is no automatic link between the active management of tensions around sustainability issues and positive outcomes for sustainability.

The study of Stadtler (2017) investigates how tensions between competition and collaboration (i.e., coopetition) play out in a cross-sector social partnership (CSSP). CSSPs bring together firms, governments, and NGOs with the aim to collaborate for the achievement of a social objective. However, since such partnerships tend to comprise more than one firm at any one time, it seems inevitable that competition between them would hamper the achievement 
of the social objective (Hahn and Pinkse 2014; Peloza and Falkenberg 2009). Instead of assuming that competition will by definition hinder the achievement of the social objective, Stadtler (2017) examines empirically how the people in charge of managing CSSPs deal with these tensions strategically so that the partnerships can increase their social impact. Her main findings emphasize the instrumental value of actively managing paradoxical tensions between collaboration and competition and between social and economic goals, respectively. In studying two CSSPs focused on education, she finds that the partnership managers deliberately used their influence over partnership design so as to use inter-firm competition as a leverage to achieve the partnerships' social objectives. Nonetheless, only one of the CSSPs turned out to be successful in doing this. With her study, Stadtler (2017) contributes to the paradox perspective on corporate sustainability by showing how partnership managers combine paradoxes of organizing with regard to partnership design and paradoxes of performing between economic and social goals and use the ensuing tensions instrumentally for social purposes.

In their conceptual article, Ivory and Brooks (2017) identify a lack of research examining organizational capabilities which contribute to the successful management of paradoxes in corporate sustainability. They highlight instrumental aspects of a paradox perspective in that they contribute to a better understanding of the mechanisms behind the successful management of paradoxical tensions in corporate sustainability. To do so, they build on Smith and Lewis' (2011) dynamic equilibrium model and in particular the distinction between the pathway of acceptance and the pathway of resolution of paradoxes. Theorizing the organizational capabilities that contribute to these pathways, they introduce the concept of strategic agility (Doz and Kosonen 2010) to paradox theory and argue that strategically agile organizations are better placed to navigate these pathways. Ivory and Brooks (2017) link the three organizational meta-capabilities of strategic sensitivity, collective commitment, and resource fluidity (Doz and Kosonen 2010) to the two pathways. They argue that strategic sensitivity and collective commitment contribute to the acceptance of paradox, and collective commitment and resource fluidity to the resolution of paradox. Finally, they identify a set of organizational practices and processes that organizations can draw on that affect their organizational meta-capabilities to manage corporate sustainability with a paradox lens.

\section{Normative Focus}

While some of the articles of this thematic symposium touch upon normative implications of a paradox perspective on corporate sustainability, none has a predominantly normative focus. Above, we have already highlighted some key questions and potential avenues to address this gap of normative research on a paradox perspective. Inherent in a paradox perspective on corporate sustainability is the acknowledgment of the intrinsic value of interrelated, yet competing sustainability issues. This normative position has two main implications. First, it posits that different sustainability objectives are each ends in themselves and that none should be systematically subordinated to any other. This equivalency of sustainability objectives links corporate sustainability to the debate on strong sustainability (Málovics et al. 2008). It raises the question to what extent there can be compromises between different competing sustainability objectives. Future research could address the normative justification for balancing competing, yet interrelated sustainability objectives without violating the need to preserve critical levels of different forms of economic, environmental, and social forms of capital.

Second, a normative perspective on paradox highlights the intrinsic value of the plurality of sustainability objectives, even if these are competing (Hahn and AragónCorrea 2015). The coexistence of different views and preferences regarding competing sustainability objectives can spur novel and innovative responses to sustainability issues. Accepting and pursuing competing sustainability objectives due to their inherent value brings into proximity competing demands; it highlights hidden connections and unconventional responses, thus creating "spaces of possibility" (Byrch et al. 2015) that go unnoticed if some sustainability objectives are selectively emphasized over others. For future research, it is, hence, essential to be aware of the inherent normative stance of a paradox perspective on corporate sustainability and the implications it has on descriptive and instrumental inquiries.

\section{Outlook and Conclusion}

This thematic symposium offers six insightful works on the emerging paradox perspective on corporate sustainability. They improve our understanding of how decision makers in various contexts deal with tensions and paradoxes around corporate sustainability (Carollo and Guerci 2017; Sharma and Jaiswal 2017; Kannothra et al. 2017) and offer insights into the mechanisms behind the consequences of addressing such tensions in defensive (Iivonen 2017) or proactive ways (Stadtler 2017; Ivory and Brooks 2017). In an effort to embed these six articles in the research field and to contribute to a common understanding of a paradox perspective on corporate sustainability, we offer a definition of the concept as well as a framework to delineate its descriptive, instrumental, and normative aspects. Our framework offers a better understanding of the various 
types of, and approaches to paradoxes, of the various outcomes, and of the normative foundations of a paradox perspective.

A paradox perspective has the potential to unshackle research on corporate sustainability from the hegemony of the business case. It provides the conceptual foundations "to abandon a purely economically driven paradigm and achieve a more balanced set of socially and environmentally responsible values" (Linnenluecke and Griffiths 2010, p. 363) in order to achieve substantive business contributions to sustainable development. Distinguishing between descriptive, instrumental, and normative aspects enables scholars and practitioners to more fully realize the potential of the paradox perspective on corporate sustainability.

First, it offers a clearer focus on relevant organizational phenomena and a more accurate description of how firms and decision makers deal with tensions among multiple interrelated, yet competing sustainability issues. A paradox perspective may well shed new light on business responses to sustainability issues that were not fully understood or even discarded because they look irrelevant or irrational from a business case perspective. Second, from an instrumental point of view a paradox perspective offers novel avenues to explain firms' responses to some of the most pressing challenges of sustainable development and the outcomes of their engagement with these challenges. Since it allows for the coexistence of interrelated but competing demands, a paradox perspective accommodates a wider range of pathways to explain how and why firms can contribute to various societal objectives. Third, a paradox perspective on sustainability provides the grounds to consider a wider range of sustainability outcomes even when immediate business benefits are absent. By acknowledging the inherent value of competing sustainability issues for their own sake, it invites scholars to rethink the finality and the purpose of the firm beyond the maximization of profits.

Distinguishing between descriptive, instrumental, and normative aspects, and emphasizing the inter-linkages among these, thus helps us to sharpen the analysis of paradox in corporate sustainability and beyond. It reminds us that an accurate description of organizational phenomena and decision makers' conduct relies on a plurality of descriptive lenses even if they are competing. It helps us to understand multiple, at times competing outcomes beyond dominant categories in a world of ever-increasing complexities. Last but not least, it invites us to reconsider the normative foundations on which any inquiry into organizational responses to societal challenges is based. Corporate sustainability is an area where tensions and paradoxes are paramount. Adopting a paradox perspective on corporate sustainability helps scholars and practitioners to overcome conceptions of corporate sustainability that systematically emphasize business outcomes over societal concerns. Responses to sustainability challenges that allow businesses and society to thrive, paradoxically, require giving up the categorical primacy of profitability so that firms can iteratively attend to various interrelated, yet competing demands for achieving economically prosperous, environmentally healthy, and socially equitable development paths.

\section{Compliance with Ethical Standards}

Conflict of interest All authors declare that they have no conflict of interest.

Ethical Approval This article does not contain any studies with human participants or animals performed by any of the authors.

Open Access This article is distributed under the terms of the Creative Commons Attribution 4.0 International License (http://crea tivecommons.org/licenses/by/4.0/), which permits unrestricted use, distribution, and reproduction in any medium, provided you give appropriate credit to the original author(s) and the source, provide a link to the Creative Commons license, and indicate if changes were made.

\section{References}

Aguilera, R. V., Rupp, D. E., Williams, C. A., \& Ganapathi, J. (2007). Putting the $\mathrm{S}$ back in corporate social responsibility: A multilevel theory of social change in organizations. Academy of Management Review, 32(3), 836-863. doi:10.5465/amr.2007. 25275678 .

Allen, S., Marshall, J., \& Easterby-Smith, M. (2015). Living with contradictions: The dynamics of senior managers' identity tensions in relation to sustainability. Organization \& Environment, 28(3), 328-348. doi:10.1177/1086026615575048.

Aram, J. D. (1989). The paradox of interdependent relations in the field of social issues in management. Academy of Management Review, 14(2), 266-283. doi:10.5465/AMR.1989.4282119.

Banerjee, S. B. (2008). Corporate social responsibility: The good, the bad and the ugly. Critical Sociology, 34(1), 51-79. doi:10.1177/ 0896920507084623.

Bansal, P. (2002). The corporate challenges of sustainable development. Academy of Management Executive, 16(2), 122-131. doi:10.5465/AME.2002.7173572.

Bansal, P. (2005). Evolving sustainably: A longitudinal study of corporate sustainable development. Strategic Management Journal, 26(3), 197-218. doi:10.1002/smj.441.

Battilana, J., Sengul, M., Pache, A.-C., \& Model, J. (2015). Harnessing productive tensions in hybrid organizations: The case of work integration social enterprises. Academy of Management Journal, 58(6), 1658-1685. doi:10.5465/amj.2013. 0903.

Beech, N., Burns, H., de Caestecker, L., MacIntosh, R., \& MacLean, D. (2004). Paradox as invitation to act in problematic change situations. Human Relations, 57(10), 1313-1332. doi:10.1177/ 0018726704048357.

Berger, I. E., Cunningham, P. H., \& Drumwright, M. E. (2007). Mainstreaming corporate social responsibility: Developing markets for virtue. California Management Review, 49(4), 132-157. doi:10.2307/41166409. 
Boons, F., \& Lüdeke-Freund, F. (2013). Business models for sustainable innovation: State-of-the-art and steps towards a research agenda. Journal of Cleaner Production, 45, 9-19. doi:10.1016/j.jclepro.2012.07.007.

Byrch, C., Milne, M. J., Morgan, R., \& Kearins, K. (2015). Seeds of hope? Exploring business actors' diverse understandings of sustainable development. Accounting, Auditing \& Accountability Journal, 28(5), 671-705. doi:10.1108/AAAJ-08-2013-1438.

Calton, J. M., \& Payne, S. L. (2003). Coping with paradox: Multistakeholder learning dialogue as a pluralist sensemaking process for addressing messy problems. Business and Society, 42(1), 7-42. doi:10.1177/0007650302250505.

Carollo, L., \& Guerci, M. (2017). 'Activists-in-a-suit': Paradoxes and metaphors in sustainability managers' identity work. Journal of Business Ethics. doi:10.1007/s10551-017-3582-7.

Carroll, A. B., \& Shabana, K. M. (2010). The business case for corporate social responsibility: A review of concepts, research and practice. International Journal of Management Reviews, 12(1), 85-105. doi:10.1111/j.1468-2370.2009.00275.x.

Clegg, S. R., da Cunha, J. V., \& e Cunha, M. P. (2002). Management paradoxes: A relational view. Human Relations, 55(5), 483-503. doi:10.1177/0018726702555001.

Donaldson, T., \& Preston, L. E. (1995). The stakeholder theory of the corporation: Concepts, evidence, and implications. Academy of Management Review, 20(1), 65-91. doi:10.5465/AMR.1995. 9503271992.

Donaldson, T., \& Walsh, J. P. (2015). Toward a theory of business. Research in Organizational Behavior, 35, 181-207. doi:10.1016/ j.riob.2015.10.002.

Doz, Y. L., \& Kosonen, M. (2010). Embedding strategic agility: A leadership agenda for accelerating business model renewal. Long Range Planning, 43(2), 370-382. doi:10.1016/j.lrp.2009.07.006.

Ferraro, F., Pfeffer, J., \& Sutton, R. I. (2005). Economics language and assumptions: How theories can become self-fulfilling. Academy of Management Review, 30(1), 8-24. doi:10.5465/ AMR.2005.15281412.

Fiss, P. C., \& Zajac, E. J. (2006). The symbolic management of strategic change: Sensegiving via framing and decoupling. Academy of Management Journal, 49(6), 1173-1193. doi:10. 5465/amj.2006.23478255.

Freeman, R. E., Wicks, A. C., \& Parmar, B. (2004). Stakeholder theory and "the corporate objective revisited". Organization Science, 15(3), 364-369. doi:10.1287/orsc.1040.0066.

Gao, J., \& Bansal, P. (2013). Instrumental and integrative logics in business sustainability. Journal of Business Ethics, 112(2), 241-255. doi:10.1007/s10551-012-1245-2.

Garriga, E., \& Melé, D. (2004). Corporate social responsibility theories: Mapping the territory. Journal of Business Ethics, 53(1), 51-71. doi:10.1023/B:BUSI.0000039399.90587.34.

Ghadiri, D. P., Gond, J.-P., \& Brès, L. (2015). Identity work of corporate social responsibility consultants: Managing discursively the tensions between profit and social responsibility. Discourse \& Communication, 9(6), 593-624. doi:10.1177/ 1750481315600308 .

Gladwin, T. N., Kennelly, J. J., \& Krause, T.-S. (1995). Shifting paradigms for sustainable development: Implications for management theory and research. Academy of Management Review, 20(4), 874-907. doi:10.2307/258959.

Griffiths, A., \& Petrick, J. A. (2001). Corporate architectures for sustainability. International Journal of Operations \& Production Management, 21(12), 1573-1585. doi:10.1108/0144357011 0410919.

Gupta, A. K., \& Govindarajan, V. (2000). Knowledge flows within multinational corporations. Strategic Management Journal, 21(4), 473-496. doi:10.1002/(SICI)1097-0266(200004)21: 4<473:AID-SMJ84>3.0.CO;2-I.
Haffar, M., \& Searcy, C. (2015). Classification of trade-offs encountered in the practice of corporate sustainability. Journal of Business Ethics. doi:10.1007/s10551-015-2678-1.

Hahn, T., \& Aragón-Correa, J. A. (2015). Toward cognitive plurality on corporate sustainability in organizations: The role of organizational factors. Organization \& Environment, 28(3), 255-263. doi: $10.1177 / 1086026615604446$.

Hahn, T., \& Figge, F. (2011). Beyond the bounded instrumentality in current corporate sustainability research: Toward an inclusive notion of profitability. Journal of Business Ethics, 104(3), 325-345. doi:10.1007/s10551-011-0911-0.

Hahn, T., Figge, F., Pinkse, J., \& Preuss, L. (2010). Trade-offs in corporate sustainability: You can't have your cake and eat it. Business Strategy and the Environment, 19(4), 217-229. doi:10. 1002/bse.674.

Hahn, T., \& Pinkse, J. (2014). Private environmental governance through cross-sector partnerships: Tensions between competition and effectiveness. Organization \& Environment, 27(2), 140-160. doi:10.1177/1086026614530996.

Hahn, T., Pinkse, J., Preuss, L., \& Figge, F. (2015). Tensions in corporate sustainability: Towards an integrative framework. Journal of Business Ethics, 127(2), 297-316. doi:10.1007/ s10551-014-2047-5.

Hahn, T., Pinkse, J., Preuss, L., \& Figge, F. (2016). Ambidexterity for corporate social performance. Organization Studies, 37(2), 213-235. doi:10.1177/0170840615604506.

Hahn, T., Preuss, L., Pinkse, J., \& Figge, F. (2014). Cognitive frames in corporate sustainability: Managerial sensemaking with paradoxical and business case frames. Academy of Management Review, 39(4), 463-487. doi:10.5465/amr.2012.0341.

Hart, S. L., \& Sharma, S. (2004). Engaging fringe stakeholders for competitive imagination. Academy of Management Executive, 18(1), 7-18. doi:10.5465/ame.2004.12691227.

Held, M. (2001). Sustainable development from a temporal perspective. Time \& Society, 10(2/3), 351-366. doi:10.1177/ 0961463X01010002011.

Huzzard, T., \& Östergren, K. (2002). When norms collide: Learning under organizational hypocrisy. British Journal of Management, 13(S2), S47-S59. doi:10.1111/1467-8551.13.s2.5.

Iivonen, K. (2017). Defensive responses to strategic sustainability paradoxes-Have your coke and drink it too! Journal of Business Ethics. doi:10.1007/s10551-017-3580-9.

Ivory, S. B., \& Brooks, S. B. (2017). Managing Corporate Sustainability with a paradoxical lens: lessons from strategic agility. Journal of Business Ethics. doi:10.1007/s10551-017-3583-6.

Jay, J. (2013). Navigating paradox as a mechanism of change and innovation in hybrid organizations. Academy of Management Journal, 56(1), 137-159. doi:10.5465/amj.2010.0772.

Jennings, P. D., \& Zandbergen, P. A. (1995). Ecologically sustainable organizations: An institutional approach. Academy of Management Review, 20(4), 1015-1052. doi:10.2307/258964.

Kallio, T. (2007). Taboos in corporate social responsibility discourse. Journal of Business Ethics, 74(2), 165-175. doi:10.1007/s10551006-9227-x.

Kannothra, C. G., Manning, S., \& Haigh, N. (2017). How hybrids manage growth and social-business tensions in global supply chains: The case of impact sourcing. Journal of Business Ethics. doi:10.1007/s10551-017-3585-4.

Kaptein, M., \& Wempe, J. (2001). Sustainability management. Balancing conflicting economic, environmental and social corporate responsibilities. Journal of Corporate Citizenship, 1(2), 91-106. doi:10.9774/GLEAF.4700.2001.su.00011.

Kleiman, S., Ng, S. W., \& Popkin, B. (2012). Drinking to our health: Can beverage companies cut calories while maintaining profits? Obesity Reviews, 13(3), 258-274. doi:10.1111/j.1467-789X. 2011.00949.x. 
Kolk, A., \& Pinkse, J. (2008). A perspective on multinational enterprises and climate change: Learning from 'an inconvenient truth'? Journal of International Business Studies, 39(8), 1359-1378. doi:10.1057/jibs.2008.61.

Lewis, M. W. (2000). Exploring paradox: Toward a more comprehensive guide. Academy of Management Review, 25(4), 760-776. doi:10.5465/amr.2000.3707712.

Linnenluecke, M. K., \& Griffiths, A. (2010). Corporate sustainability and organizational culture. Journal of World Business, 45(4), 357-366. doi:10.1016/j.jwb.2009.08.006.

Lüscher, L. S., \& Lewis, M. W. (2008). Organizational change and managerial sensemaking: Working through paradox. Academy of Management Journal, 51(2), 221-240. doi:10.5465/amj.2008. 31767217.

Maletič, M., Maletič, D., Dahlgaard, J. J., Dahlgaard-Park, S. M., \& Gomišček, B. (2014). Sustainability exploration and sustainability exploitation: From a literature review towards a conceptual framework. Journal of Cleaner Production, 79, 182-194. doi:10. 1016/j.jclepro.2014.05.045.

Málovics, G., Csigéné, N. N., \& Kraus, S. (2008). The role of corporate social responsibility in strong sustainability. The Journal of Socio-Economics, 37(3), 907-918. doi:10.1016/j. socec.2006.12.061.

Margolis, J. D., \& Walsh, J. (2003). Misery loves companies: Rethinking social initiatives by business. Administrative Science Quarterly, 48(2), 268-305. doi:10.2307/3556659.

McWilliams, A., \& Siegel, D. S. (2011). Creating and capturing value: Strategic corporate social responsibility, resource-based theory, and sustainable competitive advantage. Journal of Management, 37(5), 1480-1495. doi:10.1177/0149206310385696.

Midttun, A. (2007). Corporate responsibility from a resource and knowledge perspective towards a dynamic reinterpretation of $\mathrm{C}(\mathrm{S}) \mathrm{R}$ : Are corporate responsibility and innovation compatible or contradictory? Corporate Governance, 4(2), 401-413.

Miron-Spektor, E., Gino, F., \& Argote, L. (2011). Paradoxical frames and creative sparks: Enhancing individual creativity through conflict and integration. Organizational Behavior and Human Decision Processes, 116(2), 229-240. doi:10.1016/j.obhdp.2011. 03.006.

Mitchell, R. K., Weaver, G. R., Agle, B. R., Bailey, A. D., \& Carlson, J. (2016). Stakeholder agency and social welfare: Pluralism and decision making in the multi-objective corporation. Academy of Management Review, 41(2), 252-275. doi:10.5465/amr.2013. 0486.

Neumayer, E. (1999). Weak versus strong sustainability: Exploring the limits of two opposing paradigms. Cheltenham: Elgar.

Nijhof, A. H. J., \& Jeurissen, R. J. M. (2010). The glass ceiling of corporate social responsibility: Consequences of a business case approach towards CSR. International Journal of Sociology and Social policy, 30(11/12), 618-631. doi:10.1108/01443331011085222.

O'Reilly, C. A., \& Tushman, M. L. (2008). Ambidexterity as a dynamic capability: Resolving the innovator's dilemma. Research in Organizational Behavior, 28, 185-206. doi:10.1016/j. riob.2008.06.002.

Orlitzky, M., Schmidt, F. L., \& Rynes, S. L. (2003). Corporate social and financial performance: A meta-analysis. Organization Studies, 24(3), 403-441. doi:10.1177/0170840603024003910.

Padilla, E. (2002). Intergenerational equity and sustainability. Ecological Economics, 41(1), 69-83. doi:10.1016/S0921-8009(02) 00026-5

Peloza, J., \& Falkenberg, L. (2009). The role of collaboration in achieving corporate social responsibility objectives. California Management Review, 51(3), 95-113. doi:10.2307/41166495.

Poole, M. S., \& Van de Ven, A. H. (1989). Using paradox to build management and organization theories. Academy of Management Review, 14(4), 562-587. doi:10.5465/AMR.1989.4308389.
Porter, M. E., \& Kramer, M. R. (2011). Creating shared value: How to reinvent capitalism-And unleash a wave of innovation and growth. Harvard Business Review, 89(1/2), 62-77.

Purser, R. E., Park, C., \& Montuori, A. (1995). Limits to anthropocentrism: Toward an ecocentric organization paradigm? Academy of Management Review, 20(4), 1053-1089. doi:10. 5465/AMR.1995.9512280035.

Quinn, D. P., \& Jones, T. M. (1995). An agent morality view of business policy. Academy of Management Review, 20(1), 22-42. doi: $10.2307 / 258885$.

Raisch, S., \& Birkinshaw, J. (2008). Organizational ambidexterity: Antecedents, outcomes, and moderators. Journal of Management, 34(3), 375-409. doi:10.1177/0149206308316058.

Reinecke, J., \& Ansari, S. (2015). When times collide: Temporal brokerage at the intersection of markets and developments. Academy of Management Journal, 58(2), 618-648. doi:10.5465/ amj.2012.1004.

Richardson, B. J., \& Cragg, W. (2010). Being virtuous and prosperous: SRI's conflicting goals. Journal of Business Ethics, 92(1), 21-39. doi:10.1007/s10551-010-0632-9.

Rivoli, P., \& Waddock, S. (2011). "First they ignore you...": The time-context dynamic and corporate responsibility. California Management Review, 53(2), 87-104. doi:10.1525/cmr.2011.53. 2.87.

Rodrigo, P., \& Arenas, D. (2008). Do employees care about CSR programs? A typology of employees according to their attitudes. Journal of Business Ethics, 83(2), 265-283. doi:10.1007/s10551007-9618-7.

Salzmann, O., Ionescu-Somers, A., \& Steger, U. (2005). The business case for corporate sustainability: Literature review and research options. European Management Journal, 23(1), 27-36. doi:10. 1016/j.emj.2004.12.007.

Schad, J., Lewis, M. W., Raisch, S., \& Smith, W. K. (2016). Paradox research in management science: Looking back to move forward. Academy of Management Annals, 10(1), 5-64. doi:10.1080/ 19416520.2016.1162422.

Scherer, A., Palazzo, G., \& Seidl, D. (2013). Managing legitimacy in complex and heterogeneous environments: Sustainable development in a globalized world. Journal of Management Studies, 50(2), 259-284. doi:10.1111/joms.12014.

Schreck, P. (2011). Reviewing the business case for corporate social responsibility: New evidence and analysis. Journal of Business Ethics, 103(2), 167-188. doi:10.1007/s10551-011-0867-0.

Schwartz, M. S., \& Carroll, A. B. (2008). Integrating and unifying competing and complementary frameworks. The search for a common core in the business and society field. Business and Society, 47(2), 148-186. doi:10.1177/0007650306297942.

Sharma, G., \& Good, D. (2013). The work of middle managers: Sensemaking and sensegiving for creating positive social change. The Journal of Applied Behavioral Science, 49(1), 95-122. doi:10.1177/0021886312471375.

Sharma, G., \& Jaiswal, A. K. (2017). Unsustainability of sustainability: cognitive frames and tensions in bottom of the pyramid projects. Journal of Business Ethics. doi:10.1007/s10551-0173584-5.

Slawinski, N., \& Bansal, P. (2012). A matter of time: The temporal perspectives of organizational responses to climate change. Organization Studies, 33(11), 1537-1563. doi:10.1177/ 0170840612463319.

Slawinski, N., \& Bansal, P. (2015). Short on time: Intertemporal tensions in business sustainability. Organization Science, 26(2), 531-549. doi:10.1287/orsc.2014.0960.

Smith, W. K., Gonin, M., \& Besharov, M. L. (2013). Managing social-business tensions: A review and research agenda for social enterprise. Business Ethics Quarterly, 23(3), 407-442. doi:10. 5840/beq201323327. 
Smith, W. K., \& Lewis, M. W. (2011). Toward a theory of paradox: A dynamic equilibrium model of organizing. Academy of Management Review, 36(2), 381-403. doi:10.5465/amr.2009.0223.

Stadtler, L. (2017). Tightrope walking: Navigating competition in multi-company cross-sector social partnerships. Journal of Business Ethics. doi:10.1007/s10551-017-3579-2.

Staudenmayer, N., Tyre, M., \& Perlow, L. (2002). Time to change: Temporal shifts as enablers of organizational change. Organization Science, 13(5), 583-597. doi:10.1287/orsc.13.5.583.7813.

Steurer, R., Langer, M., Konrad, A., \& Martinuzzi, A. (2005). Corporations, stakeholders and sustainable development I: A theoretical exploration of business-society relations. Journal of Business Ethics, 61(3), 263-281. doi:10.1007/s10551-005-70540 .

Stuckler, D., McKee, M., Ebrahim, S., \& Basu, S. (2012). Manufacturing epidemics: The role of global producers in increased consumption of unhealthy commodities including processed foods, alcohol, and tobacco. PLOS Medicine, 9(6), e1001235. doi:10.1371/journal.pmed.1001235.

Sundaramurthy, C., \& Lewis, M. (2003). Control and collaboration: Paradoxes of governance. Academy of Management Review, 28(3), 397-415. doi:10.5465/amr.2003.10196737.

Van der Byl, C. A., \& Slawinski, N. (2015). Embracing tensions in corporate sustainability: A review of research from win-wins and trade-offs to paradoxes and beyond. Organization \& Environment, 28(1), 54-79. doi:10.1177/1086026615575047.

van Marrewijk, M., \& Werre, M. (2003). Multiple levels of corporate sustainability. Journal of Business Ethics, 44(2), 107-119. doi:10.1023/A:1023383229086.
Vilanova, M., Lozano, J. M., \& Arenas, D. (2009). Exploring the nature of the relationship between CSR and competitiveness. Journal of Business Ethics, 87(1), 57-69. doi:10.1007/s10551008-9812-2.

WCED. (1987). Our common future. Oxford: World Commission on Environment and Development and Oxford University Press.

Welford, R. (1997). Hijacking environmentalism. Corporate responses to sustainable development. London: Earthscan.

Whiteman, G., Walker, B., \& Perego, P. (2013). Planetary boundaries: Ecological foundations for corporate sustainability. Journal of Management Studies, 50(2), 307-336. doi:10.1111/j.14676486.2012.01073.x.

Woodman, R. W., Sawyer, J. E., \& Griffin, R. W. (1993). Toward a theory of organizational creativity. Academy of Management Review, 18(2), 293-321. doi:10.5465/amr.1993.3997517.

Wright, C., Nyberg, D., \& Grant, D. (2012). "Hippies on the third floor": Climate change, narrative identity and the micro-politics of corporate environmentalism. Organization Studies, 33(11), 1451-1475. doi:10.1177/0170840612463316.

Yuan, W., Bao, Y., \& Verbeke, A. (2011). Integrating CSR initiatives in business: An organizing framework. Journal of Business Ethics, 101(1), 75-92. doi:10.1007/s10551-010-0710-z.

Zuindeau, B. (2007). Territorial equity and sustainable development. Environmental Values, 16(2), 253-268. doi:10.3197/ 096327107780474564. 